\title{
People's Behavior of North Indralaya of Ogan Ilir Against Wetland Fires
}

\author{
Dany Hernowo ${ }^{1}$, Mona Lestari $^{*}$, Novrikasari ${ }^{1}$, Widya Lionita ${ }^{2}$, Adisyah Fitrah Rahmadini ${ }^{1}$, \\ Titi Nurhaliza ${ }^{1}$
}

1 Occupational Safety and Health Department, Public Health, Faculty of Public Health, Sriwijaya University;

${ }^{2}$ Health Promotion Department, Public Health, Faculty of Public Health, Sriwijaya University

\begin{abstract}
ABSTRAK
Konversi lahan dari fungsi aslinya mengakibatkan dampak negatif berupa kebakaran akibat aktivitas penebangan untuk membuka lahan yang dilakukan manusia. Salah satu lokasi kebakaran lahan basah di Provinsi Sumatera Selatan terjadi pada area seluas 3,925 ha di Kabupaten Ogan Ilir di tahun 2018. Kelalaian manusia yang seringkali melakukan pembukaan lahan dengan cara membakar menyebabkan kebakaran lahan basah. Kurangnya pengetahuan, informasi dan sanksi juga menjadi alasan masyarakat tidak perduli terhadap dampak yang ditimbulkan dari kegiatan membakar lahan. Dalam theory of planned behavior, perilaku tersusun dari keyakinan dan evaluasi seseorang untuk menumbuhkan sikap, norma subjektif, dan kontrol perilaku sebagai mediator terbentuknya niat. Desain penelitian yang digunakan dalam penelitian bersifat kualitatif dengan pendekatan deskriptif, yaitu mengkaji dan menganalisis persepsi masyarakat terhadap kejadian kebakaran di lahan basah Ogan Ilir Sumatera Selatan. Informan penelitian berjumlah 16 orang yang terdiri dari 12 informan kunci dan 4 informan ahli. Informan kunci dipilih berdasarkan kriteria kepemilikan tanah, lokasi tempat tinggal dan mata pencaharian utama yang berdomisi di Desa Palem Raya dan Kelurahan Timbangan, Kecamatan Indralaya Utara. Empat orang informan ahli ialah Badan Penanggulangan Bencana Daerah (BPBD), Camat Indralaya Utara, dan dua orang kepala desa/lurah. Hasil penelitian menunjukkan bahwa sikap terhadap perilaku, norma subjektif, dan persepsi kontrol mendorong terbentuknya niat masyarakat Kecamatan Indralaya Utara untuk tidak melakukan pembakaran lahan. Sejak 2019, masyarakat tidak lagi membuka lahan dengan cara dibakar karena sudah ada peraturan pemerintah yang tegas sehingga dapat mengendalikan perilaku masyarakat dalam membakar lahan.
\end{abstract}

Kata kunci: Kebakaran, Lahan basah, Persepsi, Masyarakat, Theory of planned behavior

\begin{abstract}
Land conversion from its original function resulted in negative impacts in the form of fires due to logging activities to clear land by humans. One of wetland fires located in South Sumatera Province is happened to 3,925 ha area on Ogan Ilir District in 2018. Human negligence which often clears land by burning caused of wetland fires. Lack of knowledge, information and sanctions are also reasons why people don't care about the impact of land burning activities. The theory of planned behavior states that behavior is composed of individual belief and evaluation to foster attitudes, subjective norms, and behavioral control as mediators of intention. The research design used in this study is qualitative with a descriptive approach, which is to examine and analyze public perceptions of the occurrence of fires in the Ogan Ilir wetlands of South Sumatera. The research informants are 16 persons consisted 12 key informants and 4 expert informants. Key informants are choosen by land ownership, the main livelihood, and residence location which all come from Palem Raya and Timbangan Village. Four expert informants are the representative of Regional Disaster Management Agency (BPBD), Subdistrict Head of North Indralaya, and two Village Head. The results showed that attitudes, subjective norms, and behavioral control encourage community's intention in North Indralaya for not doing land fire anymore. Since 2019, community did not open the land by burning because of the strict regulation by government so that can control behavior related land fire.
\end{abstract}

Keywords: Fire, Wetland, Behavior, Community, Theory of planned behavior

Citation: Hernowo, D., Lestari, M., Novrikasari, N., Lionita, W., Rahmadini, A.F., and Nurhaliza, T. (2022). People’s Behavior of North Indralaya of Ogan Ilir Against Wetland Fires. Jurnal Ilmu Lingkungan, 20(2),316-324; doi:10.14710/jil.20.2.316-324

\section{Introduction}

The perceptions that each individual has make the individual better understand the state of the personal self. Perception is a unified and interconnected activity, all feelings, experiences, thinking skills and other aspects that exist in the individual will play a role in shaping perception (Agustin and Khuzaini, 2018). If a person has a perception of something, then it will have the intention to perform a behavior.

*Penulis korespondensi: mona lestari@unsri.ac.id 
According to Ajzen in the theory of planned behavior, behaviors with high engagement require confidence and evaluation to foster attitudes, subjective norms, and behavior control as mediators of the influence of various motivational factors that can have an impact on behavior (Ajzen, 1991). The theory of planned behavior provides a framework for the study of attitudes toward behavior where intentions are the most important determinants of behavior (Ajzen and Fishbein, 2012). In this theory, attitudes toward behavior, subjective norms, and perceptions of behavior control will give rise to the intention to perform a behavior.

The wetland fire in Indonesia which is currently considered a global disaster event due to the impact of fires that spread to neighboring countries and burning gases can potentially cause global warming (Rauf, 2016). Countries often affected by wetland fires in Indonesia include Southern Thailand, Singapore, Malaysia, and Brunei Darussalam (Ho Et, 2014).

As population growth increases, increasing the need for residential and agricultural land, this leads to many wetland habitats being converted into residential land and agricultural land (Faturrahma, 2019). Land conversion from its original function resulted in a negative impact in the form of fires due to logging activities to open land carried out by humans (Lestari et al., 2021). Human negligence that often does land clearing by burning is often the cause of wetland fires. The impact can affect land and outside the wetland system (Rauf, 2016).

South Sumatra Forest Service reported land and forest fires that occurred in Ogan Ilir Regency in 2014 amounted to 17,728 ha, in 2015 amounted to 12,297 ha, in 2017 amounted to 2,614 ha and in 2018 again increased by 3,925 ha. In 2019 there were land fires with an increasing quantity from the previous year. The increase in land fires that occurred in South Sumatra devoured an area of 52,716 ha. Land fires for the South Sumatra region in 2019 began in April or the beginning of the dry season. Wetland fires, particularly peat soils are very dangerous and difficult to detect especially if they occur in the dry season (Nurhayati, Hero Saharjo, Sundawati, Syartinillia, \& Vetrita, 2020).

Some factors such as economic, cultural, and social backgrounds of people have a perspective that burning land for land clearing is the easiest and cheapest way. The habits that exist in the community to open land by burning have become one of the aspects of culture that develop in the community. Based on social musts, the community argues that if burning land will lead to land expansion so that they do not need to open their own land (Asnawi, 2016). Perception in the community affects the incidence of land fires because the community thinks that burning land to open land will be more effective and cheaper and fast. According to Ariani and Bambang (2018), Perception will be the determining factor of the community in doing land clearing. Lack of knowledge, information and sanctions is also the reason people do not care about the impact caused by burning land.

\section{Method}

The research design is qualitative with a descriptive approach, which is to review and analyze people's perception of fire events in Ogan Ilir's wetlands of South Sumatra. The research was conducted in several villages in North Indralaya, Ogan Ilir, which had high and low fire incidence rates. The sources of information in this study were divided into expert informants and key informants.

Key informant are 16 persons lived in Palem Raya Village and Timbangan District. These locations are selected because of having the highest (Palem Raya Village) and lowest (Timbangan District) fire incidents in 2019. Key informants are selected through some criteria such as type of land ownership (as landlord or not), main livelihood (as farmer or not), and type of residence (close or far from hotspot) (See Picture 1). For data triangulation, four expert informants are choosen, they are one representative of Regional Disaster Management Agency (BPBD), Subdistrict Head of North Indralaya, and two village head. The study was conducted from February 2021 to June 2021.

Primary data collection is conducted by means of in-depth interviews about fire behavior in wetlands. Secondary data used as a support for research is the profile of the research site and data obtained from Badan Penanggulangan Bencana Daerah (BPBD) Ogan Ilir, South Sumatera. Data that has been obtained from the results of in-depth interviews and observations will then be analyzed using qualitative analysis methods and presented in the form of impressionist narratives is a style of writing where the experience and impression of researchers while in the field.

\section{Results and Discussion}

\subsection{Characteristic of Informants}

Total informants of this study are sixteen persons; twelve as key informants and four as expert informants. Most of key informants are men (75\%), below fifty years old (58.33\%), with education level below senior high school. (58.33\%). In the other hand, expert informants $50 \%$ women, mostly upper 30 years old $(75 \%)$ and with education level above senior high school (75\%). 


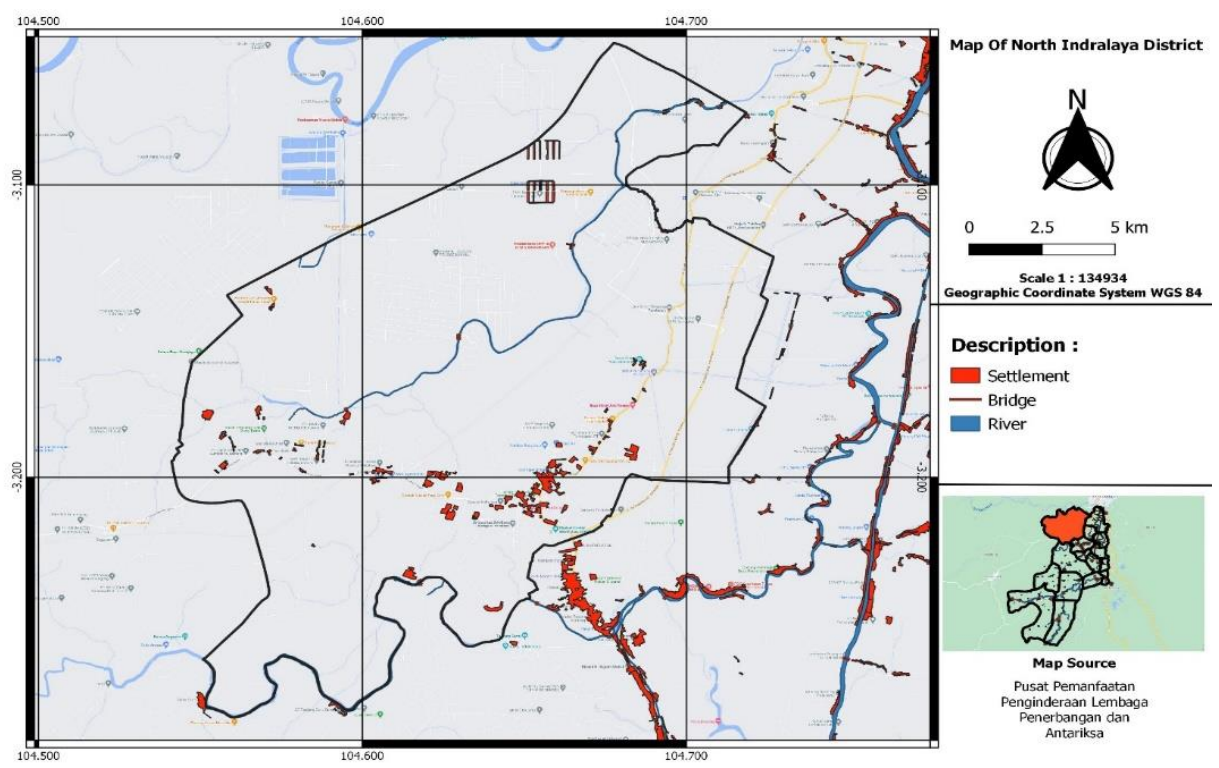

Figure 1 Map of North Indralaya

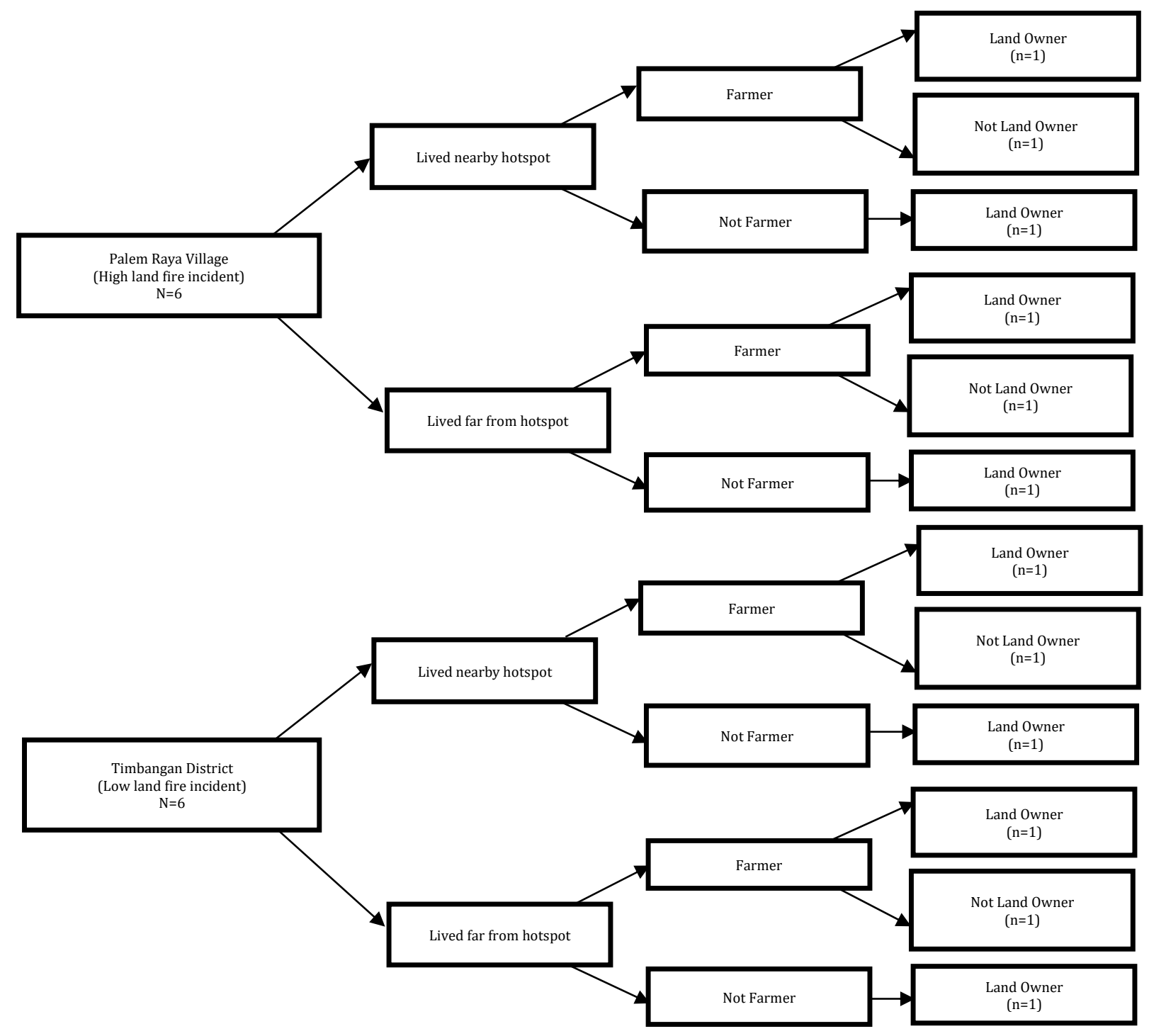

Figure 2 Flow Diagram of Key Informants 


\subsection{Attitudes toward Behavior}

According to Ajzen (2005), attitudes toward behavior is determined through the belief of the consequences of a behavior or called behavioral beliefs (behavioral beliefs) and individual evaluation. In the other hand, attitude can also be influenced by the level of positive or negative assessment of the individual towards the behavior.

Each community's knowledge of wetland fires is different. Based on the results of interviews, nine of twelve key informants know that they live in a wetland environment. About $41.67 \%$ said type of the land is peatland. Related to the experienced of witnessing a landfire, those who lived in Palem Raya Village are more often to see it than Timbangan district. Within one last year, five of six informants confessed landfire happen 3 times or more. Based on the information obtained land fires are caused by human factors and natural factors. Mainly (58.33\%) think land fire occurred as the result of cigarette butts being thrown carelessly, either form passers-by, anglers, or farmer who work while smoking. In addition, natural factors such as drought and dry land are also triggers for land fires.

\begin{abstract}
"Peatland, but only $30 \mathrm{~cm}$ deep... For this year, it (land fire) happens 5 or 6 times... Because of human factor. Maybe they accidentally, while walking thrown cigarette butts carelessly." (Key-AM)
\end{abstract}

\begin{abstract}
"My land is peatland... For now (fire land) never happen again... Hmm, I do not know, seems like because of dry season or someone burn trash, sparks fly everywhere" (Key-AR)

"Many factors, by natural factor if it is realy an extreme condition, there are also intentional and unintentional factors. For example, anglers who thrown cigarette butts accidentally" (Expert-DS)
\end{abstract}

Some natural factors are the cause of forest fires such as strong winds, droughts, coal, and others. Fires that occur in the dry season due to the accumulation of litter or foliage, heat, wind, and rock friction in the dry season so as to trigger the emergence of fire (Arisanty, Anis, Putro, Muhaimin, \& Syarifuddin, 2020). According to BNPB (2013), fires are caused by fires used in the clearing and preparation of land for human activities such as plantations, agriculture, land preparation for transmigrants, and industrial plantation forests. This land preparation activity often causes fires to become uncontrolled and spread to other forest areas. Based on information obtained from interviews with the people in North Indralaya, people no longer burn land to open land so the average incidence of land fires caused by careless human behavior that throws cigarette butts or the act of burning garbage that causes sparks to spread.
Almost all key informants (91.67\%) said that the impact of land fires on health included shortness of breath, smog interfered visibility and sore eyes. In addition, its ashes can contaminate water sources and surrounding environment. This statement was also corroborated by expert informants who stated that land fires are not only impact to human, but also the environment.

"The smog interferes with breating, visions, the environment becomes dirty because of flying ash" (Key-BY)

"Yes, exactly shortness of breath and smoke, to the environment is smog" (Key-ARW)

"Its smoke especially to eyes and breathing caused Accute Respiratory Infection. If the environment more like destruction of soil ecosystem and air polluted." (Expert-YI)

In addition to the impact on health, the impact on the environment is quite large. Wetland fires cause greater damage and loss to the environment than soil and minerals (Rahmi et al., 2015). Wetland fires can cause degradation of the wetland environment conditions such as reduced resources in the soil and reduced carbon sequestration function. Burning wetlands can lead to loss of biomass in soil layers as well as lead to decreased soil thickness and increased soil porosity (Purwowidodo, 1998).

The knowledge that peoples have influences the attitudes taken by society in behaving. Beliefs are concerned with an individual's subjective assessment of the surrounding environment, the individual's understanding of the self and the environment, done by linking behavior with benefits or losses that will be obtained if done or not done. The attitude that a person has is based on trust in the outcome that will be produced (Wikamorys and Rochmach, 2017).

Attitude is an evaluation that is positive or negative involving one's emotions in responding to social objects, meaning that if the result is positive then someone tends to approach the object and vice versa if the result is negative it will tend to be shunned (Rahayu et al., 2014). Knowledge of the impacts that can harm their health causes them to abandon the habit of burning wetlands to clear land. According to Wawan and Dewi (2011), behavior is a response to a stimulus that comes from outside as well as from within the human being.

\subsection{Subjective Norms}

Subjective norms are the perceptions that individuals have of the expectations of people who have an influence in their lives regarding the doing or not doing a behavior (Ramdhani, 2011). Subjective norms consist of the environment or environtment, the closest circle or closer circle, and the attributes of successful entrepreneurs or attributes of the successful entrepreneur (Caecilia, 2012). 
Table 1. The Result of Indepth Interview From Key Informants

\begin{tabular}{|c|c|c|c|c|c|c|c|c|c|c|c|c|}
\hline \multirow{2}{*}{$\begin{array}{l}\text { Question of Depth } \\
\text { Interview }\end{array}$} & \multicolumn{12}{|c|}{ Sample of Key Informant Coding } \\
\hline & \multicolumn{6}{|c|}{ Palem Raya Village } & \multicolumn{6}{|c|}{ Timbangan district } \\
\hline $\begin{array}{ll}\begin{array}{l}\text { Attitude } \\
\text { Behavior }\end{array} & \text { Toward } \\
\end{array}$ & AM & $\mathrm{L}$ & BY & FR & $\mathrm{S}$ & $\mathrm{JK}$ & AR & ARW & $\mathrm{N}$ & DP & GS & IW \\
\hline $\begin{array}{l}\text { "If land fire happens } \\
\text { around your residence, } \\
\text { how do you react to it?" }\end{array}$ & $\begin{array}{l}\text { Firm action } \\
\text { from MPA, } \\
\text { inform } \\
\text { farmer or } \\
\text { angler, not } \\
\text { to throw } \\
\text { cigarettes } \\
\text { butt }\end{array}$ & $\begin{array}{l}\text { Annoyed, } \\
\text { no } \\
\text { responsibility } \\
\text { from actor }\end{array}$ & $\begin{array}{l}\text { Annoyed, } \\
\text { angry, } \\
\text { if fire hits } \\
\text { his land }\end{array}$ & $\begin{array}{l}\text { Worried, } \\
\text { must give } \\
\text { punishment }\end{array}$ & $\begin{array}{l}\text { Quite } \\
\text { disturbed, } \\
\text { can harm } \\
\text { others, by } \\
\text { its smog }\end{array}$ & $\begin{array}{l}\text { Okay if not } \\
\text { harm other, } \\
\text { unforgivable } \\
\text { if harm } \\
\text { other }\end{array}$ & $\begin{array}{l}\text { Hard to } \\
\text { change } \\
\text { people } \\
\text { behavior, } \\
\text { public } \\
\text { figure } \\
\text { needs to } \\
\text { educate } \\
\text { people, } \\
\text { not to fire } \\
\text { the land }\end{array}$ & $\begin{array}{l}\text { As chief } \\
\text { farmer, } \\
\text { reminds to } \\
\text { not use old } \\
\text { style, more } \\
\text { benefit (fire } \\
\text { land) but } \\
\text { never think } \\
\text { about its } \\
\text { impact }\end{array}$ & $\begin{array}{l}\text { Give } \\
\text { immediate } \\
\text { action, } \\
\text { worried if } \\
\text { his house } \\
\text { will be } \\
\text { fired }\end{array}$ & $\begin{array}{l}\text { Actor must be } \\
\text { arrested, pay } \\
\text { compensation, } \\
\text { so it does not } \\
\text { happen again }\end{array}$ & $\begin{array}{l}\text { Quite } \\
\text { worried, } \\
\text { harm to } \\
\text { other } \\
\text { people, } \\
\text { harm to } \\
\text { environment }\end{array}$ & $\begin{array}{l}\text { Should be } \\
\text { reprimanded, } \\
\text { so it does not } \\
\text { happen again, } \\
\text { ask for } \\
\text { responsibility, } \\
\text { will blame } \\
\text { each other }\end{array}$ \\
\hline \multicolumn{13}{|l|}{ Subjective Norm } \\
\hline $\begin{array}{l}\text { "How many people in } \\
\text { your community who } \\
\text { still open the land using } \\
\text { fire?" }\end{array}$ & No one do it & No one do it & $\begin{array}{l}\text { No one do } \\
\text { it, since } \\
2018\end{array}$ & $\begin{array}{l}\text { No one do } \\
\text { it }\end{array}$ & $\begin{array}{l}\text { No one do } \\
\text { it, they are } \\
\text { afraid }\end{array}$ & No one do it & $\begin{array}{l}\text { Since } 2019 \\
\text { no one do } \\
\text { it, } \\
\text { someone } \\
\text { has been } \\
\text { arrested }\end{array}$ & $\begin{array}{l}\text { No one do it, } \\
\text { most people } \\
\text { knew } \\
\text { regulation }\end{array}$ & $\begin{array}{l}\text { Maybe } \\
\text { there is no } \\
\text { one do it, } \\
\text { do not } \\
\text { really } \\
\text { know }\end{array}$ & $\begin{array}{l}\text { Maybe there } \\
\text { is no one do it, } \\
\text { they are afraid }\end{array}$ & No one do it & $\begin{array}{l}\text { Do not really } \\
\text { know, he does } \\
\text { not use it } \\
\text { again }\end{array}$ \\
\hline \multicolumn{13}{|l|}{$\begin{array}{l}\begin{array}{l}\text { Perceived } \\
\text { Control }\end{array} \\
\end{array}$} \\
\hline $\begin{array}{l}\text { "Do you know if there is } \\
\text { regulation made by } \\
\text { government about land } \\
\text { fire?" }\end{array}$ & $\begin{array}{l}\text { There is } \\
\text { rule, } \\
\text { categorized } \\
\text { as criminal } \\
\text { law }\end{array}$ & $\begin{array}{l}\text { Rules not to } \\
\text { fire forest } \\
\text { and land }\end{array}$ & $\begin{array}{l}\text { Rules not } \\
\text { to fire } \\
\text { forest and } \\
\text { land, in } \\
\text { South } \\
\text { Sumatera }\end{array}$ & $\begin{array}{l}\text { Categorized } \\
\text { as criminal } \\
\text { law, if it is } \\
\text { intentional }\end{array}$ & $\begin{array}{l}\text { Do not } \\
\text { know }\end{array}$ & $\begin{array}{l}\text { There is } \\
\text { rule, for } \\
\text { peatland } \\
\text { fire }\end{array}$ & $\begin{array}{l}\text { There is } \\
\text { rule, } \\
\text { informed } \\
\text { by BPBD, } \\
\text { when it } \\
\text { happens }\end{array}$ & $\begin{array}{l}\text { Rules not to } \\
\text { fire land, if it } \\
\text { is intentinal, } \\
\text { categorized as } \\
\text { criminal law, } \\
\text { pay } \\
\text { compensation, } \\
\text { will be jailed }\end{array}$ & $\begin{array}{l}\text { There is } \\
\text { rule, rules } \\
\text { not to fire, } \\
\text { for } \\
\text { peatland } \\
\text { fire }\end{array}$ & $\begin{array}{l}\text { Rules not to } \\
\text { fire land }\end{array}$ & $\begin{array}{l}\text { Rules not to } \\
\text { fire land, } \\
\text { information } \\
\text { around road } \\
\text { side and } \\
\text { banner }\end{array}$ & $\begin{array}{l}\text { Rules not to } \\
\text { fire forest }\end{array}$ \\
\hline \multicolumn{13}{|l|}{ Intention } \\
\hline $\begin{array}{l}\text { "How do you prepare to } \\
\text { open the land?" }\end{array}$ & $\begin{array}{l}\text { Manually } \\
\text { for small } \\
\text { land, use } \\
\text { machine if } \\
\text { land is wide }\end{array}$ & Nothing & $\begin{array}{l}\text { Manually, } \\
\text { use } \\
\text { machine } \\
\text { (tractor), } \\
\text { depends to } \\
\text { farmer } \\
\text { who use it }\end{array}$ & Manually & $\begin{array}{l}\text { Cutting, } \\
\text { Clearing } \\
\text { the land, } \\
\text { Digging the } \\
\text { soil for } \\
\text { blending } \\
\text { with } \\
\text { fertilizer } \\
\text { (manually) }\end{array}$ & $\begin{array}{l}\text { Use machine } \\
\text { (plow) }\end{array}$ & $\begin{array}{l}\text { Hire } \\
\text { someone } \\
\text { else, } \\
\text { cutting } \\
\text { grass with } \\
\text { sickle, } \\
\text { collecting } \\
\text { trash }\end{array}$ & $\begin{array}{l}\text { Use machine } \\
\text { (plow) }\end{array}$ & $\begin{array}{l}\text { Covered } \\
\text { with soil }\end{array}$ & $\begin{array}{l}\text { Use machine } \\
\text { (tractor), soil } \\
\text { must be } \\
\text { plowed before } \\
\text { planting }\end{array}$ & $\begin{array}{l}\text { Manually if } \\
\text { it is open } \\
\text { land, use } \\
\text { machine if } \\
\text { something } \\
\text { gets in soil }\end{array}$ & Manually \\
\hline
\end{tabular}


A total of 5 out of 12 key informants stated that land fire is no longer done since 2019. Although, there is still someone who burn trash or dry grass after clearing the land. The community has stopped burning activities to clear land due to social sanctions imposed and legal sanctions.

" Long time ago, they were using burning method to open the land but now people are afraid of getting arrested" (Key-DP)

"Alhamdulillah since 2019, because someone has been arrested too, no more clearing land by burning" (Key-AR)

"No one else did that (land fire) ... Only burn the trash like dry leaves of grass" (Key-L)

"In this Timbangan village, Alhamdulillah there is no people who open the land by burning anymore. Beside someone still manage their waste by burning" (Expert-SA)

All of key informants feel that society is disturbed by burning to open the land. Besides most of them $(58.33 \%)$ stated land fire caused society health problems, they were also worried if the fire spread to their land. When a fire occurred, nine of all key informants said that the community would immediately work together to extinguish the fire. Cooperation between the community and the government and related agencies is needed to overcome the impact of land fires.

"Quite disturbing... It is quite disturbing yeah, especially if someone really have intention set fire to it... participates in mutual cooperation with other residents to extinguish the fire" (KeyFR)

"Obviously disturbed Bro, the smoke made shortness in breathing. We as farmer are worried if the fire comes to our land... the response is we work together for distinguishing the fire" (Key-DP)

"We are from subdistrict staff have been collaborated to National Board for Disaster Management (BNPB), Regional Disaster Management Agency of Ogan Ilir (BPBD OI), Manggala Agni, police, soldier and MPA of each village consist of 10 persons at least" (ExpertRM)

Subjective norms refer to the influence of others on individuals, in this case governments, other societies, and the social environment. Subjective norms can be said to be the result of a person's belief in what others or other social groups think. This is combined with the motivation and goals of the individual to adjust behavior to social norms that apply in their environment (Permatasari, 2015).

In accordance with the above, the community is concerned about how the habits of other communities in doing land clearing. The behavior of people in the social environment that no longer do land burning affects the behavior of other communities not to burn to open land. The community will seek to change the behavior of burning land in connection with the encouragement and pressure of the surrounding environment. In addition, the motivation of individuals to avoid diseases caused by fire smoke and environmental impacts makes the community change previous behavior. Subjective norms will be high if people believe that society will feel greatly benefited by changes in behavior.

\subsection{Perceived Behavioral Control}

An individual's perception of the ease or difficulty of realizing a behavior is called behavior control perception (Ajzen, 2005b). Perception of behavioral control is a function based on control beliefs, which are a person's beliefs about supporting factors or inhibitions in eliciting behavior (Sigit, 2006). Based on the results of the study, the impact is not only on their health, but also on the possibility of their land being burned then the plants wither and fail to harvest. In addition to these impacts, the controlling factor is the existence of regulations that have been implemented. Almost all key informants already know about government regulations on fires and socialization carried out by the government.

“.. moreover, it can harmful to others, its smoke flies everywhere, the fire can spread to other's land... I know, the prohibition of burning land if it violates there is a criminal law that has regulated it" (Key-AM)

"If materially can be millions. Farmer can fail to harvest. To our health, it can cause Accute Resporatory Infection." (Key-DP)

"Many are taped to the roadside, banners from the police to not burn land" (Key-GS)

"I know, it is regulation about government restriction to fire forest and land. When someone intentionally is done burning, he could be convicted, like pay compensation and being prisoned for 5 years without trial" (Expert-DS)

Local authorities including BPBD and the Village Chief conduct socialization and patrols to warn residents about fires. Palem Raya Village is more often to inform society since land fire still happen on their area. Different with Timbangan district, which land fires have rarely occurred, the socialization has rarely been done but the community is still reminded about the impact and punishment when burning land.

"Ehh... every time we do the morning, afternoon and night patrol. If there is someone around the wetland or anglers, we always remind them to be carefull of their cigarette butts" (Expert-DS) 
"For now, we barely do the socialitation since in this area (Timbangan district), wetlands fire is rare and almost never happen again, the last time it happened, it was in 2019, someone burned the land to open the land" (Expert-SA)

"Frequently, especially in the dry season. From village apparatus and $B P B D$, everytime they do partrol, it must be socialized." (Key-L)

"I do not know for sure; the last socialization is when land fire happened in 2019, that is it." (Key-N)

Behavioral control indicates the extent to which an individual can control what he or she displays and does not display (Maskur et al., 2015). Socialization about the impact of land fires and punishment of severe arsonists becomes the motivation or reason of the community not to burn land. In line with Permatasari (2015) behavioral control is determined by a belief in factors that can encourage a behavior or as a deterrent not to perform it. According to Azjen in Ramdhani (2011), if the condition of behavior control is strong and convincing and the individual has enough information so that this will strengthen the motivation of the individual in determining the behavior.

\subsection{Intention}

Planned Behavior Theory is an improvement over reasoned action theory. Reasoned action theory has evidence that the intention to carry out an act or behavior results from subjective norms and attitudes towards behavior (Seni and Ratnadi, 2017). The other factor is the perception of behavior control that turns reasoned action theory into planned behavior theory.

Planned behavior according to Ajzen (2005) is a disposition of behavior that will turn into a form of action when the right time and opportunity. According to Bandura in Permatasari (2015), Intention is the basis for shaping behavior in individuals and determining subsequent circumstances based on the drive, purpose, and self-determination to perform a particular activity.

This study find that seven key informants choose manual way to open the land by using grass cutter/sickle or pay anyone to clear it. If the land is wide, they usually use plows like tractor. The reasons are these methods would not damage the elements in the soil that affect fertility (33.33\%) and also, they afraid of being caught if they burning the land (16.67\%). Therefore, non of key informants used fire to clear the land.

"Alhamdulillah, all the farming communities here are using plow machines... One, so that the roots can be lifted ang the soil can be turned over. It is possible that there is fertilizer on it. Let the land be fertile." (Key-ARW)
"Actually, my land is cleaned manually, sometimes using tractor, depends on the farmer who is riding on my land now... That was not allowed by burning. Instead of getting into trouble, it is better to lose a little bit" (Key-BY)

"Personally, I pay somebody to clear it, Bro. Most of the time, grass is cut with a sickle. Then it will be collected... Because if it wants to be burned, honestly, I am also afraid of being arrested. We all do not know anybody's personality, right? It is possible when we are burning it, someone take our picture and then report to the police." (Key-AR)

Planned behavior theory explains that attitudes toward behavior are one of the important parts that can be the reason in determining an action. When a person appreciates a positive deed, then he will have the will to do the deed and vice versa. The view of people who view the impact of land fires as a negative gives rise to the desire not to commit acts of land burning. People believe that by not burning land it can benefit them. Therefore, the negative impact and benefits are what cause the community's intention not to burn land is higher. In line with research conducted by Wikamorys dan Rochmach (2017), Attitudes toward behavior have a significant influence on a person's intention to perform a behavior.

The environment has an important role in a person's decision-making (Subagyo, 2000). People who are in a social environment where the surroundings have a positive influence will increase motivation to perform a behavior. The social environmental conditions of the community in North Indralaya who no longer do land burning again make each other's motivation among the community not to do land burning behavior. In line with research conducted by Wahyuningsih (2018) in the intense use of cosmetics, subjective norms have a positive and significant influence on consumer intentions to buy cosmetics and halal skincare products. Research by Hartoni and Riana (2015) subjective norms have a positive influence on the intention of workers to use PPE. If subjective norms tend to be good and high, an individual's confidence to implement or display a behavior will be higher. In addition, the growth of caring attitudes among fellow communities characterized by gotong royong activities in the event of a fire makes one of the motivations of the community not to burn forests.

A person's behavior is influenced by a control on which he or she is based. Behavioral control has two aspects: how much a person has control over behavior and how confident one is about the ability to perform a behavior or not to do so (Hidayah and Haryani, 2012). In this case, the socialization that has been done by the local authorities and the increasingly burdensome punitive sanctions become community control so as not to burn land. People in North Indralaya are already aware of the prison sanctions and fines that will be 
received if they commit land burning. In addition, the socialization carried out by BPBD and the Village Head makes the community more aware and does not burn. People are also aware of the many benefits felt if they do not burn forests, making the motivation to change bad behavior to burn land. In line with research by Ma'sumah and Pujiati (2018), behavioral control has a positive value, meaning that behavioral control has a positive influence on intention.

In accordance with the theory of planned behavior, intention is a direct determinant of the behavior then it can be known that the behavior of the individual will be consistent with his intention towards the behavior. Intention will play a role in eliciting an action or behavior by linking between the components of attitudes toward behavior, subjective norms, and behavior control.

\section{Conclusion}

Based on the results of the study, it can be concluded that attitudes towards behavior have a support on the intention of the people of North Indralaya not to burn land. This means that the high response or positive attitude of the community towards the act of not burning land will lead to the intention not to burn land. As well as subjective norm have also a positive encouragement towards the intention of the people of North Indralaya not to burn land. They already consider that by burning the land, the society near it will be disturbed, especially related to health such as shortness of breath, smog and sore eyes. This means that the more other people that do not burn land, the greater one's intention not to burn land. The third one is personal behavioral control that has a role to form on the intention of the people of North Indralaya not to burn land. This means that the greater the benefits and many factors that inhibit burning land such as punitive sanctions, the stronger one's intention not to burn land.

\section{Acknowledgement}

The research/publication of this article was funded by DIPA of Public Service Agency of Universitas Sriwijaya 2021. SP DIPA-023.17.2.677515/2021, On November 23, 2020. In accordance with the Rector's Decree Number: 0007/UN9/SK.LP2M.PT/202I, On April 27, 2021.

\section{References}

Agustin, A., \& Khuzaini. (2018). Persepsi Masyarakat terhadap Penggunaan Transportasi Online (Grab) di Surabaya. Jurnal Ilmu Dan Riset Manajemen, 6(9), 1-18.

Ajzen. (2005a). Attides, Personallity and Behavior. International Journal of Strategic Innovative Marketing, Vol. 3, p. 117.
Ajzen, I. (1991). The Theory of Planned Behavior Organizational Behavior and Human Decision Processes, 50(1991), 179-211.

Ajzen, I. (2005b). Attitudes, Personality and Behavior (Second). Open University Press.

Ajzen, I., \& Fishbein, M. (2012). Belief, Attitude, Intention and Behavior: An Introduction to Theory and Research. MA: Addison-Wesley.

Ariani, T., \& Bambang, H. (2018). Pengetahuan dan Persepsi Masyarakat Desa Rawasari di Sekitar Hutan Lindung Gambut Londerang Terkait Kebakaran Hutan Kabupaten Tanjung Jabung Timur. Pendidikan Biologi Universitas Jambi.

Arisanty, D., Anis, M. Z. A., Putro, H. P. N., Muhaimin, M., \& Syarifuddin. (2020). Kebakaran Lahan Gambut: Faktor Penyebab dan Mitigasinya (Pertama). Banjarmasin: Program Studi Pendidikan IPS, Fakultas Keguruan dan Ilmu Pendidikan, Universitas Lambung Mangkurat.

Asnawi. (2016). Fire zones and the threat to the wetlands of Sumatra, Indonesia.

BNPB. (2013). Rencana Kontijensi Nasional Menghadapi Ancaman Bencana Kabut Asap Akibat Kebakaran Hutan dan Lahan.

Caecilia, V. S. (2012). Faktor-Faktor yang Mempengaruhi Intensi Berwirausaha Siswa SMK. Jurnal Pendidikan Vokasi, 2(1), 117-126.

Faturrahma, N. Z. (2019). Analisis Faktor Alam terhadap Kejadian Kebakaran Lahan Basah di Kabupaten Ogan Ilir Provinsi Sumatera Selatan 2019. Universitas Sriwijaya.

Hartoni, I. G. P. O., \& Riana, I. G. (2015). Sikap, norma subjektif, dan kontrol perilaku pada implementasi keselamatan kerja: Dampaknya terhadap intention to comply (Studi pada pekerja kontraktor PT. Hutama Karya Kantor Wilayah IV Bali, NTB, NTT). E Jurnal Ekonomi Dan Bisnis Universitas Udayana, 4(4), 243-264.

Hidayah, S., \& Haryani. (2012). Implementasi Niat (Intention) dalam Kehidupan Kerja. Dharma Ekonomi, 12(36), 1-8.

Ho Et. (2014). Membakar lahan gambut sama artinya dengan membuat polusi asap. Project Fire Fight South EastAsia.

Lestari, M., Andarini, D., Camelia, A., Novrikasari, N., Nandini, R. F., \& Fujianti, P. (2021). Wetland Fires and Its Environmental Conditions. Jurnal Ilmu Lingkungan, 19(1), 21-28.

Ma'sumah, N., \& Pujiati, A. (2018). Pengaruh Sikap, Norma Subjektif dan Kontrol Perilaku Persepsian terhadap Niat Berwirausaha Siswa. Economic Education Analysis Journal, 7(1), 194-207.

Maskur, A., Saeroji, A., \& Tjahjaningsih, E. (2015). Pengaruh Norma Subjektif dan Kontrol Prilaku yang Dipersepsikan Terhadap Niat Pinjam Kur Mikro (Studi pada Nasabah BRI di Pati). UNISBANK, 1(1), 978-979.

Nurhayati, A. D., Hero Saharjo, B., Sundawati, L., Syartinillia, \& Vetrita, Y. (2020). Perilaku dan persepsi masyarakat terhadap terjadinya kebakaran gambut di Ogan Komeriling Ilir Provinsi Sumatera Selatan. Jurnal Pengelolaan Sumberdaya Alam Dan Lingkungan (Journal of Natural Resources and Environmental Management), 10(4), 568-583.

Permatasari, L. P. (2015). Pengaruh Sikap, Norma Subjektif, Dan Kontrol Perilaku Terhadap Intensi Berhenti Merokok Sebagai Dampak Peraturan Gambar Peringatan Pada Mahasiswa Strata Satu Di Kota Malang. Jurnal Ilmiah Mahasiswa FEB, 3(2), 1-10.

Purwowidodo. (1998). Mengenal Tanah Hutan dan Penampang Tanah. Bogor: Laboratororimu Pengaruh 
Hutan Fakultas Kehutanan IPB.

Rahayu, C., Widiati, S., Widyanti, N., Kesehatan, P., Tasikmalaya, K., Kedokteran, F., ... Mada, G. (2014). Hubungan antara Pengetahuan, Sikap , dan Perilaku terhadap Pemeliharaan Kebersihan Gigi dan Mulut dengan Status Kesehatan Periodontal Pra Lansia di Posbindu Kecamatan Indihiang Kota Tasikmalaya. Majalah Kedokteran Gigi, 21(1), 27-32.

Rahmi, O., Susanto, R. H., \& Siswanto, A. (2015). Pengelolaan Lahan Basah Terpadu di Desa Mulia Sari Kecamatan Tanjung Lago, Kabupaten Banyuasin (The Integrated Lowland Management in Mulia Sari, Tanjung Lago Subdistrict, Banyuasin Regency). Jurnal Ilmu Pertanian Indonesia, 20(3), 201-207.

Ramdhani, N. (2011). Penyusunan Alat Pengukur Berbasis Theory of Planned Behavior. Buletin Psikologi, 19(2), $55-69$.

Rauf, A. (2016). Dampak Kebakaran Lahan Perkebunan Kelapa Sawit Di Lahan Gambut Kabupaten Aceh Barat Daya Terhadap Sifat Tanah Gambut. Jurnal Pertanian Tropik, 3(3), 256-266.

Seni, N. N. A., \& Ratnadi, N. M. D. (2017). Theory of Planned Behavior Untuk Memprediksi Niat Berinvestasi. E
Jurnal Ekonomi Dan Bisnis Universitas Udayana, 12(6), 4043-4068.

Sigit, M. (2006). Pengaruh Sikap dan Norma Subyektif Terhadap Niat Beli Mahasiswa Sebagai Konsumen Potensial Produk Pasta Gigi Close Up. Jurnal Siasat Bisnis, 11(1), 81-91.

Subagyo, A. B. (2000). Bagaimana Memprakirakan dan Memahami Perilaku. Bandung: Lembaga Literatur Baptis.

Wahyuningsih, I. (2018). Intensi Konsumen Terhadap Kosmetik Dan Produk Skincare Halal Di Indonesia: Pendekatan Theory of Planned Behavior. Jurnal of Economucs and Business Aseanomics (JEBA), 3(1), 4159.

Wawan, A., \& Dewi, M. (2011). Teori dan Pengukuran Pengetahuan, Sikap, dan Perilaku Manusia. Yogyakarta: Nuha Medika.

Wikamorys, D. A., \& Rochmach, T. N. (2017). Aplikasi Theory of Planned Behavior dalam Membangkitkan Niat Pasien Untuk Melakukan Operasi Katarak. Jurnal Administrasi Kesehatan Indonesia, 5(1), 32-40. 